\title{
JANUARY 1970
}

TENTH YEAR - No. 106
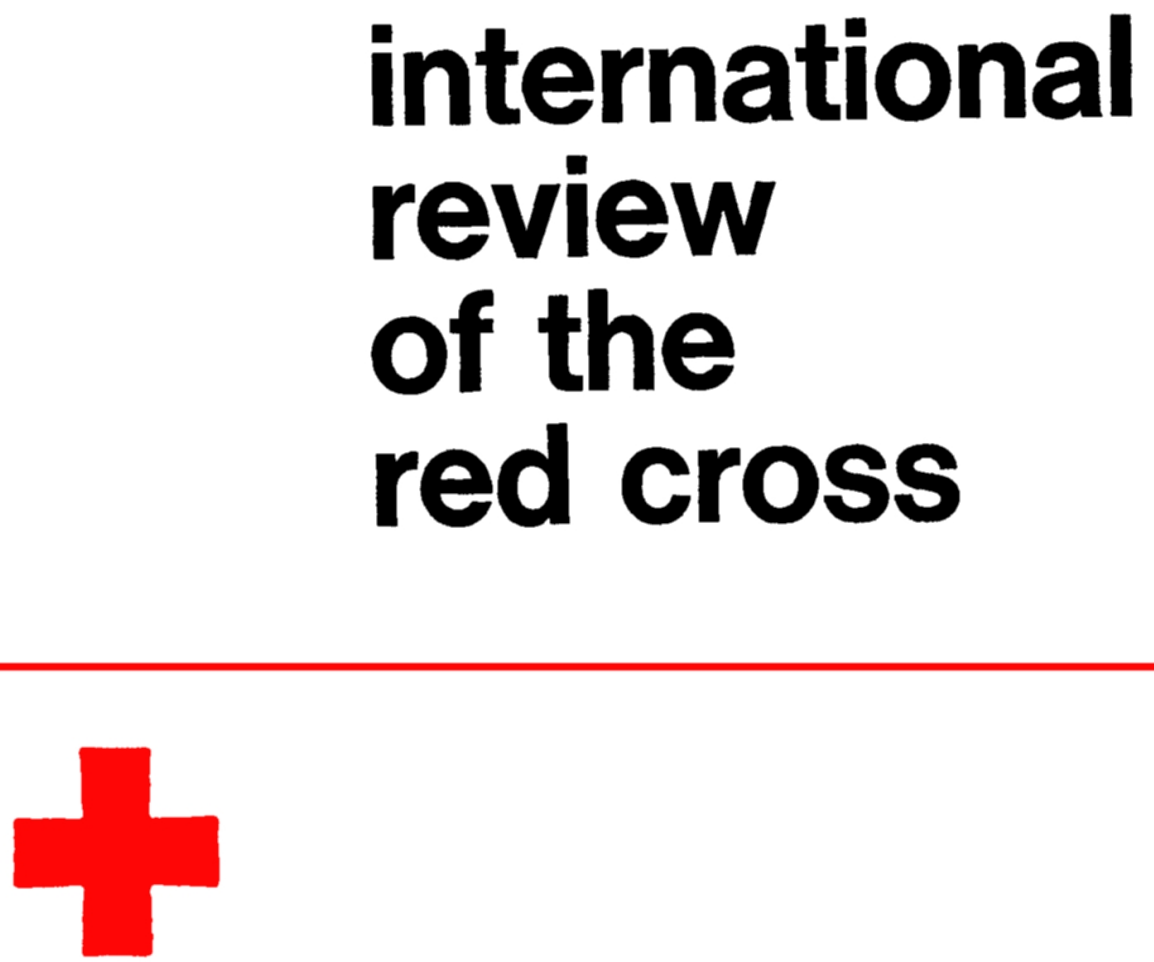

INTER ARMA CARITAS

\section{GENEVA}

INTERNATIONAL COMMITTEE OF THE RED CROSS FOUNDED IN 1863 


\section{INTERNATIONAL COMMITTEE OF THE RED CROSS}

MARCEL A. NAVILLE, Master of Arts, President (member since 1967)

MARTIN BODMER, Hon. Doctor of Philosophy (1940)

PAUL RUEGGER, former Swiss Minister to Italy and the United Kingdom, Member of the Permanent Court of Arbitration, The Hague (1948)

RODOLFO OLGIATI, Hon. Doctor of Medicine, former Director of the Don Suisse (1949)

GUILLAUME BORDIER, Certificated Engineer E.P.F., M.B.A. Harvard, Banker (1955)

HANS BACHMANN, Doctor of Laws, Assistant Secretary-General to the International Committee of the Red Cross from 1944 to 1946, Vice-President (1958)

JACQUES FREYMOND, Doctor of Literature, Director of the Graduate Institute of International Studies, Professor at the University of Geneva, Vice-President (1959)

DIETRICH SCHINDLER, Doctor of Laws, Professor at the University of Zurich (1961)

HANS MEULI, Doctor of Medicine, Brigade Colonel, former Director of the Swiss Army Medical Service (1961)

MARJORIE DUVILLARD, Deputy executive director of the International Council of Nurses (1961)

MAX PETITPIERRE, Doctor of Laws, former President of the Swiss Confederation (1961)

ADOLPHE GRAEDEI, former member of the Swiss National Council; Secretary-General of the International Metal Workers Federation (1965)

DENISE BINDSCHEDLER-ROBERT, Doctor of Laws, Professor at the Graduate Institute of International Studies (1967)

JACQUES F. DE ROUGEMONT, Doctor of Medicine (1967)

ROGER GALLOPIN, Doctor of Laws, former Director-General (1967)

JEAN PICTET, Doctor of Laws, staff member since 1937, former Director-General (1967)

WALDEMAR JUCKER, Doctor of Laws, Secretary, Union syndicale suisse (1967)

Honorary members: Mr. JACQUES CHENEVIERE, Honorary Vice-President; Miss LUCIE ODIER, Honorary Vice-President; Messrs. FRÉÉRIC BARBEY, CARL J. BURCIHARDT, PAUL CARRY, Miss SUZANNE FERRIËRE, Mrs. MARGUERITE GAUTIERVAN BERCHEM, Messrs. SAMUEL A. GONARD, EDOUARD de HALLER, PAUL LOGOZ, FREDERIC SIORDET, ALFREDO VANNOTTI, ADOLF VISCHER. 


\title{
INTERNATIONAL REVIEW OF THE RED CROSS
}

\author{
JANUARY 1970 - № 106
}

\section{INTERNATIONAL COMMITTEE OF THE RED CROSS}

IN THE RED CROSS
WORLD

MISCELLANEOUS

BOOKS AND REVIEWS
XXIst International Conference of the Red Cross - Opening Session Speeches.

External Activities :

People's Republic of South Yemen - Middle East - Vietnam - Rumania - German Federal Republic Mexico - Chad - Greece - Latin America . . . 14

Geneva :

Honorary Members of the ICRC . . . . . . . 21

Mr. Gallopin retires from Directorate . . . . 23

ICRC Reorganization . . . . . . . . . . 23

Guests of the ICRC . . . . . . . . . . . 24

$*$

Three Vaccination Campaigns . . . . . . . 26

Appeal for Victims of Nigeria Conflict . . . . 32

The Honduras-Salvador Conflict - Aid to victims by National Societies of Central America . . . 37

Bulgaria . . . . . . . . . . . . . . . 44

Morocco . . . . . . . . . . . . . . . 46

A new Stage in the Development of Humanitarian Law . . . . . . . . . . . . . . . . . 48

The 14th Quadrennial Congress of the International Council of Nurses . . . . . . . . . 51 
FRENCH EDITION

OF THE REVIEW

\section{SUPPLEMENTS}

TO THE REVIEW

SPANISH

GERMAN

INTERNATIONAL

REVIEW OF

THE RED CROSS
The French edition of this Review is issued every month under the title of Revue internationale de la Croix-Rouge. It is, in principle, identical with the English edition and may be obtained under the same conditions.

J. Pictet: La necesaria restauración de las leyes y costumbres aplicables en caso de conflicto (II).

J. Pictet: Die Notwendigkeit einer Bekräftigung der Gesetze und des Gewohnheitsrechts in bewaffneten Konflikten (II) - Weltrotkreuztag.

The International Review is published each month by the International Committee of the Red Cross

7, avenue de la Paix, 1211 Geneva I, Switzerland Postal Cheque No. 121767

Annual subscription: Sw. fr. $25 .-(\$ 6)$

Single copies Sw. fr. $2.50(\$ 0.60)$

Editor: J.-G. LOSSIER

The International Committee of the Red Cross assumes responsibility only for material over its own signature. 